Marine Biology 12, 81-98 (1972)

(c) by Springer-Verlag 1972

\title{
The Vermetidae (Mollusca: Gastropoda) of the Hawaiian Islands*
}

\author{
M. G. HAdfield ${ }^{1}$, E. A. KAY ${ }^{2}$, M. U. GILletTE ${ }^{3}$ and M. C. Lloyd ${ }^{4}$ \\ ${ }^{1}$ Pacific Biomedical Research Center, University of Hawaii; Honolulu, Hawaii, USA \\ and \\ 2 Department of General Science, University of Hawaii; Honolulu, Hawaii, USA \\ and \\ ${ }^{3}$ Department of Zoology, Scarborough College, University of Toronto; Westhill, Ontario, Canada \\ and \\ ${ }^{4}$ Department of Zoology, University of Michigan; Ann Arbor, Michigan, USA
}

\begin{abstract}
The Hawaiian vermetid fauna comprises 8 species, 7 of which are here described as new. The generic distribution includes 5 species of Dendropoma and 1 each of Petaloconchus, Vermetus and Serpulorbis. The species descriptions rely little on conchology, stressing instead descriptions of animals, habitats and reproductive and developmental characteristics. Feeding is accomplished in all species by a combination of mucous nets and detrital collection by ctenidial cilia. Only in the single species of Vermetus, an inhabitant of quiet waters, does ciliary feeding predominate. Four small species of Dendropoma inhabit shallow, coralline algal-encrusted, wave-washed reef areas, while Serpulorbis and Dendropoma platypus are found not only in intertidal areas subjected to heavy surf, but subtidally to depths of $10 \mathrm{~m}$ or more. The single species of Pelaloconchus is a characteristic associate of the 4 Dendropoma spp. of shallow waters but, being strongly associated with the coral Porites, Petaloconchus also extends subtidally. The Hawaiian vermetids are very abundant in some localities, with densities ranging up to $60,000 / \mathrm{m}^{2}$ in one species of Dendropoma. Reproduction is continuous in all Hawaiian vermetids, most of which produce small hatching juveniles rather than swimming veligers. Only Serpulorbis and Vermetus have obligatory planktonic stages. Petaloconchus and Dendropoma species may produce a mixture of hatching juveniles and short-term planktonic veligers. Larval or juvenile size is correlated with available nurse yolk, not with egg size.
\end{abstract}

\section{Introduction}

In this paper, 8 species of the prosobranch gastropod family Vermetidae, 7 of which are described as new by HADFIELD and $K_{A Y}$, are distinguished in the Hawaiian Islands, and their habits and habitats, methods of feeding, reproduction, brood protection and larval life are discussed ${ }^{\mathbf{1}}$.

* Contribution No. 374 from the Hawaii Institute of Marine Biology, University of Hawaii, Honolulu, Hawaii.

1 The following abbreviations are used for the depository museums: BPBM: Bernice P. Bishop Museum, Honolulu, Hawaii; USNM: U.S. National Museum, Washington, D. C.

\section{Species descriptions}

Genus Dendropoma Mörch, 1861

Dendropoma gregaria HADFIELD and KAY, nov. sp. (Figs. 1-2, 19 A)

Type material. holotype, BPBM (No. 8929 ; part of a large colony). Paratypes: BPBM, USNM. Type locality: Kaheka (near Koloa) Kauai, Hawaii (159 $28^{\prime} 30^{\prime \prime} \mathrm{W}$ Longitude, $21^{\circ} 52^{\prime} 30^{\prime \prime} \mathrm{N}$ Latitude) forming a dense mat on the intertidal boulders.

Shell (Fig. 1). Small (maximum apertural diameter $3 \mathrm{~mm}$ ); tubes forming compact, continuous mats. Each individual tube fits, at least through a third of its circumference, into a channel eroded into the calcareous mass of the other shells. Cross-sectional views of the raised portion of the tube may be quite angular. Exterior: deep purple black in the field, brown when cleaned; interior: dark and glossy. Earlier portions of tube sealed off by an opaque white, lens-shaped plug. Surface scaly due to numerous raised concentric lamellae.

Protoconch (Fig. 19 A). At hatching $0.9 \mathrm{~mm}$ by $0.65 \mathrm{~mm}$, of one and one-half whorls; abapical threequarters of each whorl broad, sculptured with light axial ribs crossed by finer spiral striae which are visible only by transparency. Apex often white, but major portion of protoconch brown at hatching or becoming brown in settling.

Operculum (Fig. 2). Variable in shape, from a flattened, shiny, deep red-brown disk with concentric rings to a highly domed, tough, horny cone also with concentric rings but with the rings less developed than in the domed form. There is often a small, median, terminal depression. Inner surface concave with a prominent mamilla. Border surrounded by a transparent flange. Diameter closely approximating that of the shell aperture.

Animal. Mesopodial pad brilliant lavendar pink or, occasionally, light yellow, with no intergrades be- 


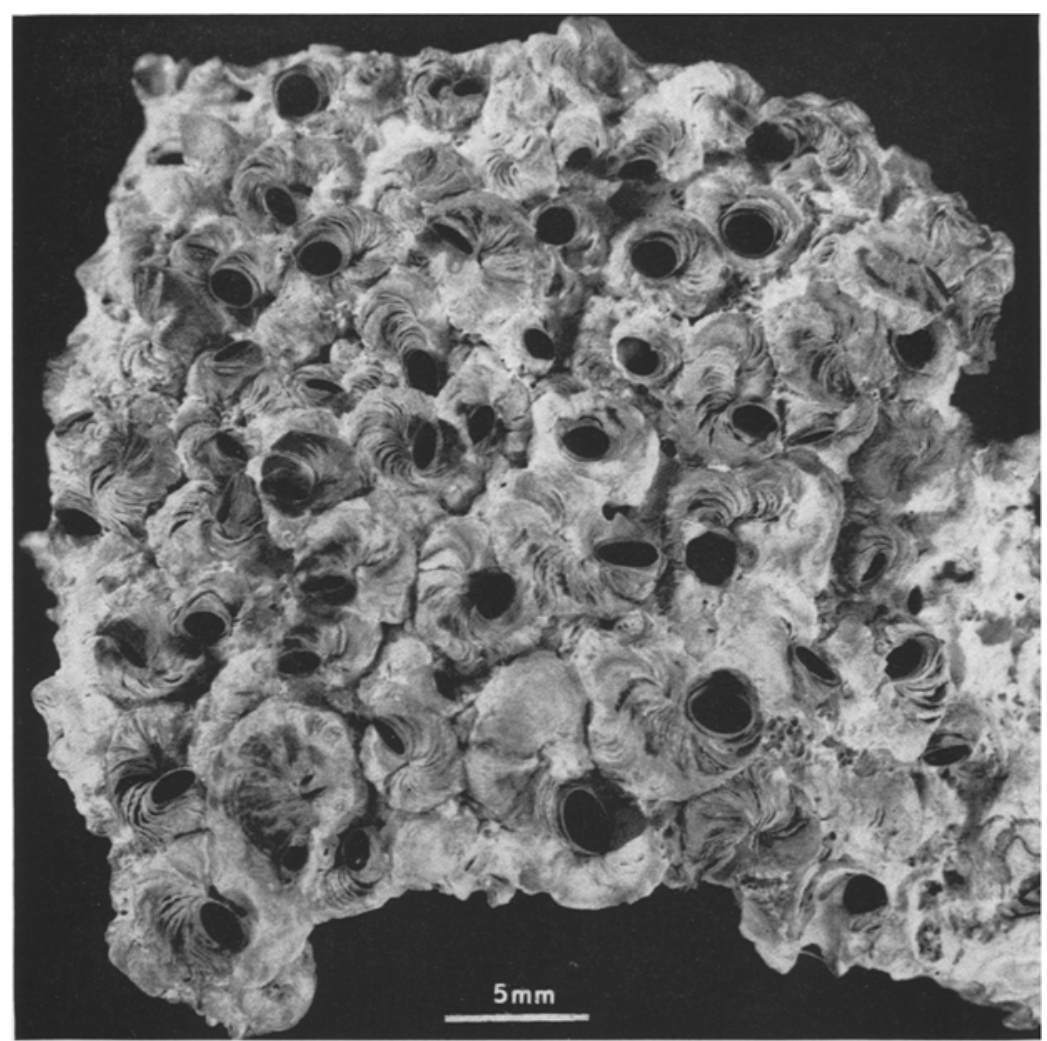

Fig. 1. Dendropoma gregaria nov. sp. Mass of adult tubes. Fifty-nine tube apertures can be seen in this piece, which measures less than $10 \mathrm{~cm}^{2}$ total area

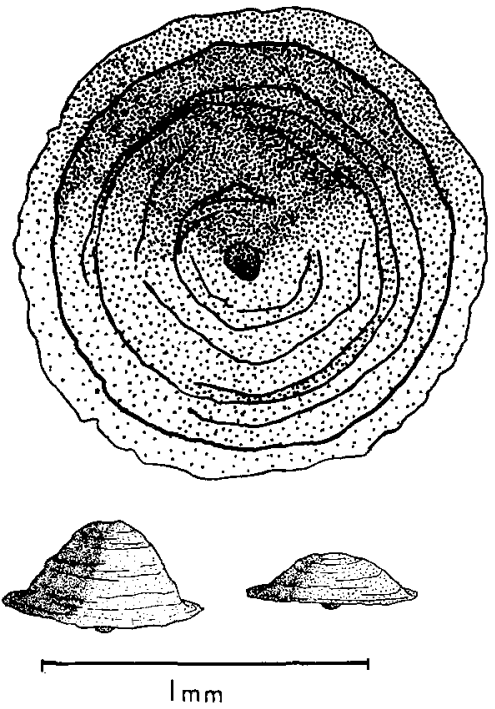

Fig. 2. Dendropoma gregaria nov. sp. Operculum

tween the two variants; ground color of remainder of foot black with superficial white speckling; head gray around proboscis, tending to black posteriorly; sides of head around eye densely white, because of concentrations of white pigment granules; pedal tentacles nearly transparent; cephalic tentacles black at bases, white at tips; mantle black except for the border which is flecked with white. Gill filaments triangular. Mantle margin entire in both sexes.

Habitat and habits. Dendropoma gregaria forms dense masses more than $5 \mathrm{~cm}$ in thickness on solution and water-levelled benches at Maile Point and Diamond Head, Oahi, and at Burns Field and Kukuiula, Kauai; the mat, which coats boulders on the benches, may extend more than $13 \mathrm{~cm}$ from the vertical surface. These vermetids appear to be restricted to a rather narrow zone about, or slightly below, the zero-tide level (United States Coast Guard Service, Hawaii datum). They are preyed on by the thaisids Morula granulata (Duccos, 1832) and Morula uva (Röding, 1798). Feeding is by mucous threads.

Brood protection and larval life. Three or four egg capsules are usually brooded at one time. Each capsule may contain from 6 to 21 eggs, the average being about 10. Early capsules appear to contain a quantity of non-cellular nurse yolk, which is consumed by the developing embryos. The capsules are ovoid, slightly more than $1 \mathrm{~mm}$ long. In capsules containing older larvae, the capsular membrane is flaccid and closely follows the contours of its contents. 
In each capsule containing older-shelled juveniles, some of the larvae are brown, others colorless. The number and percentages of brown and colorless larvae varies as follows:

\begin{tabular}{lll}
\hline No. of larvae per capsule & No. brown & No. white \\
\hline 7 & 2 & \\
8 & 6 & 5 \\
9 & 2 & 7 \\
11 & 7 & 4 \\
12 & 5 & 7 \\
13 & 6 & 7 \\
14 & 12 & 2 \\
\hline
\end{tabular}

The significance of this color variation is not at all clear. One possibility is that the brown larvae may be those which have consumed the greater share of the available nurse yolk.

The juveniles at hatching, be they brown or colorless, are all of approximately the same size. The velum of the hatching juveniles is reduced to mere ciliated ridges above each eye, and the larvae are capable of pedal locomotion. At settling, the right side of the aperture is applied to the substratum and the teleoconch, as it is secreted, adheres to the substratum. A sharp keel which projects over the head of the juvenile forms a shell roof over the aperture of early settled stages.

Comparisons. Dendropoma gregaria resembles $D$. tholia KEeN and Morton, 1960, in its colonial habit and in the shape of the operculum. The angular cross-sectional views of the tube, larval shell, and brilliantly colored foot are, however, distinctive. The specific epithet "gregaria" is descriptive of its habits.

Dendropoma meroclista HADFIELD and KAY, nov. sp. (Figs. 3, 4, 19 F)

Type material. Holotype, BPBM (No. 8931). Paratypes: BPBM, USNM. Type ocality: Mokuoloel Island (Coconut Island), Kaneohe Bay, Oahu, Hawaii $\left(157^{\circ} 47^{\prime} 10^{\prime \prime} \mathrm{W}\right.$ longitude, $21^{\circ} 26^{\prime} 10^{\prime \prime} \mathrm{N}$ latitude) on coralline algal-encrusted reef.

Shell (Fig. 3). Small (maximum tube-diameter $1.5 \mathrm{~mm}$ ); tube deeply embedded in the substrate and usually overgrown with calcareous algae, terminal portion ordinarily perpendicular to the substrate to which the shell is cemented, distal end extending 1 to $2 \mathrm{~mm}$ above substrate. Aperture almost completely closed by a convex dome of shell, leaving only a narrow slit. Exterior: typically dark purple; interior: white, sometimes stained with green; newly formed shell pinkish-brown. Seulpture of irregular axial ribs and fine concentric striae on exposed portions of the shell.

Protoconch (Fig. 19F). At hatching $0.45 \mathrm{~mm}$ by $0.35 \mathrm{~mm}$, of $1 \frac{1}{2}$ finely punctate, brown or colorless $11 *$ whorls; succeeding whorls with arched axial ribs, dark brown.

Operculum (Fig. 4A). Mushroom-shaped, fitting under the convex dome of the aperture and effectively closing it; nacreous white. Pedal surface planar except for the projecting mamilla. The apex of the opercular dome is often broken, leaving a circular hole on the external surface. It appears that the operculum is partially hollow, causing a weakness in the apex.

Animal. Head, foot, and cephalic tentacles dark purple or black with a few superficial markings; pedal tentacles distinguished by a white spot near the

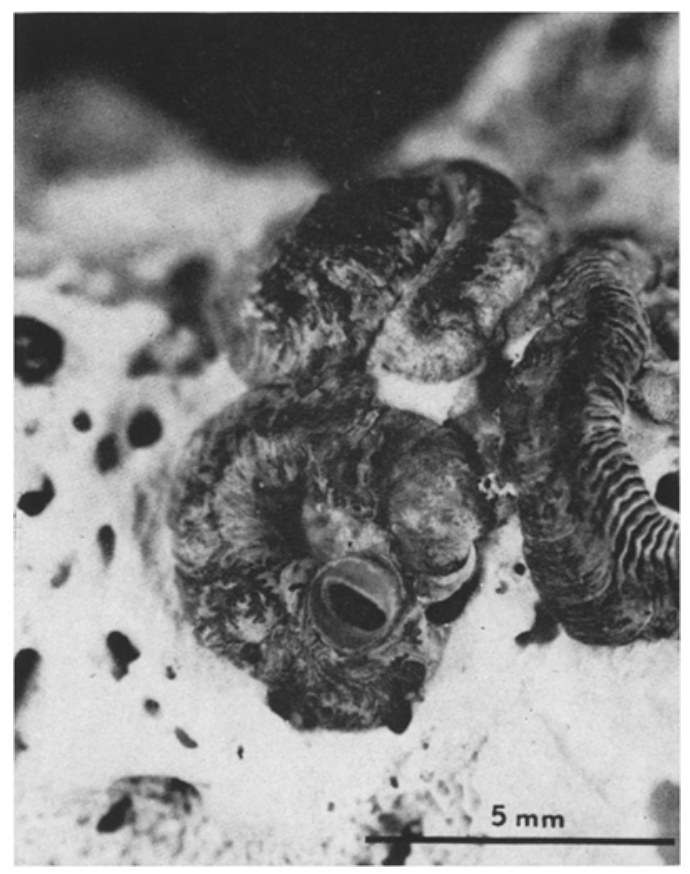

Fig. 3. Dendropoma meroclista nov. sp. Adult shell, showing diagnostic constriction of shell aperture

tips, and the foot by a prominent white spot. One pedal tentacle long and mobile, the other vestigial (Fig. 4B). Mantle margin slit in females. Gills flat, triangular plates extending one-third the diameter of the mantle cavity. Columellar muscle short, straplike, ending abruptly at the visceral coil.

Habit and habits. These small vermetids are solitary, but settle within 1 or $2 \mathrm{~mm}$ of each other, on coralline algal-encrusted coral of fringing and patch reefs such as at Waikiki, Oahu, and in Kaneohe Bay, Oahu. The tube is barely emergent from the substrate, but the partially enclosed aperture and the white, mushroom-shaped operculum immediately distinguish Dendropoma meroclista from other small Dendropoma in the same habitat. Feeding is primarily by mucous 
threads. The vermetids may periodically enlarge the shell aperture by rasping away the edges with the radula.

Brood protection and larvae. As many as 6 egg capsules are brooded at one time, each ovoid capsule

A

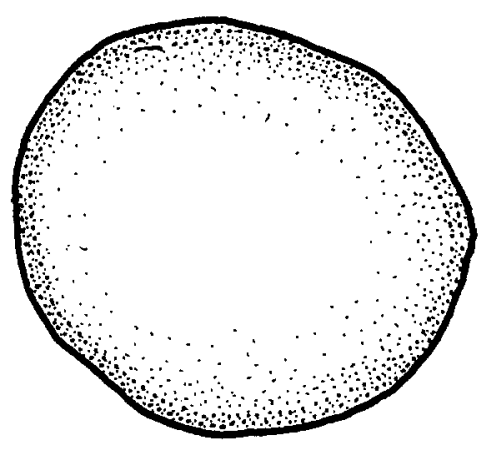

$1 \mathrm{~m} \mathrm{~m}$

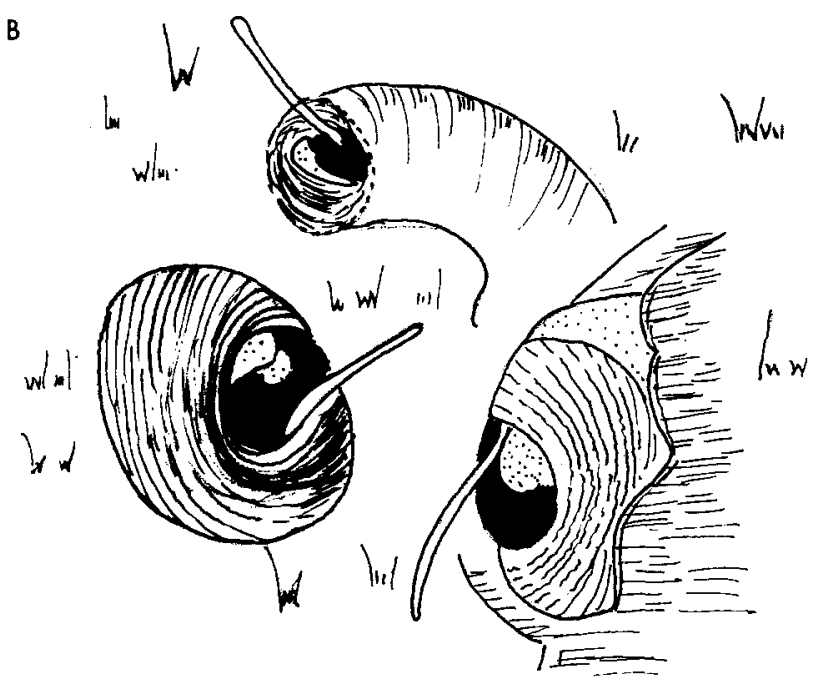

Fig. 4. Dendropoma meroclista nov. sp. (A) Operculum showing lateral and ventral views; (B) vermetids sketched in situ showing constriction of aperture and single emergent tentacle

attached to the shell by a short stalk and containing 3 to 12 eggs. The embryos have a black head, esophagus and digestive gland, and develop yellow pigmentation on the foot before they begin to crawl. Capsules containing late individuals, with the velum in the regressive state and the foot well developed as a crawling organ, are found brooded; because these larvae are too laden with yolk and shell to swim, it is assumed that direct development is the usual mode in this species. Occasional planktonic veligers have been recorded, however, in the plankton of Kaneohe Bay (TAYLOR, personal communication) and it is suggested that Dendropoma meroclista is able to produce both direct developing and planktonic forms depending upon environmental conditions.

Comparisons. Although the partially closed, domelike aperture distinguishes this species from other described Dendropoma, the vermetid is clearly Dendropoma-like in conchological and opercular characters as well as in the general organization of the body, and there seems no reason to distinguish the species generically. The specific epithet, from the Greek meaning "partly closed", is chosen in reference to the apertural features of the shell.

Dendropoma meroctista is a commonly occurring vermetid on the seaward reef flat at Eniwetok, Marshall Islands.

Dendropoma platypus MörcH, 1861 (Figs. 5, 6, 19H)

Type material. In the British Museum (Natural History) on the shell of Chama. Type locality: Hawaii.

Shell ( $F i g .5$ ). Of medium size (diameter of whorls up to $20 \mathrm{~mm}$; maximum apertural diameter $7 \mathrm{~mm}$ ). Usually tightly coiled on itself and embedded in coral or on shells. Aperture circular to slightly ovoid. Exterior porcelain white or mottled with dark brown, green and/or purple, especially in larger individuals. Upper surface with wavy axial riblets and occasionally with a keel on the dorsal surface of the coils.

Protoconch (Fig. 19H). At hatching $0.68 \mathrm{~mm}$ by $0.53 \mathrm{~mm}$, of $1 \frac{1}{2}$ to $1 \frac{2}{3}$ whorls, the second whorl sculptured with well-defined axial ribs; unpigmented and opaque or with two brown spirals, one along the suture, the other along the mid-dorsal line.

Operculum (Fig. 6A). Shaped like an inverted cone with the apex a central red spot marking the mamilla on the pedal surface and with brown spirals. Remainder of operculum clear and transparent, but often encrusted with algae in life. Larger than foot, coinciding with shell aperture.

Animal. Basic pigmentation black, but with superficial markings of yellow and white speckles; lateral edges of head with dense white spots; rolled edge of mantle intensely yellow alternating with black. Pedal tentacles long and extensible. Metapodium a thick pad medially and back of the operculum. Mantle margin entire in both sexes. Gill filaments flat, triangular lamellae extending three-quarters the diameter of the mantle cavity (Fig. 6B). Mucous gland less than half the diameter of the foot. Osphradium compact, elongate, about half the length of the gill; hypobranchial gland occupying major portion of the dorsal surface of the mantle cavity. 


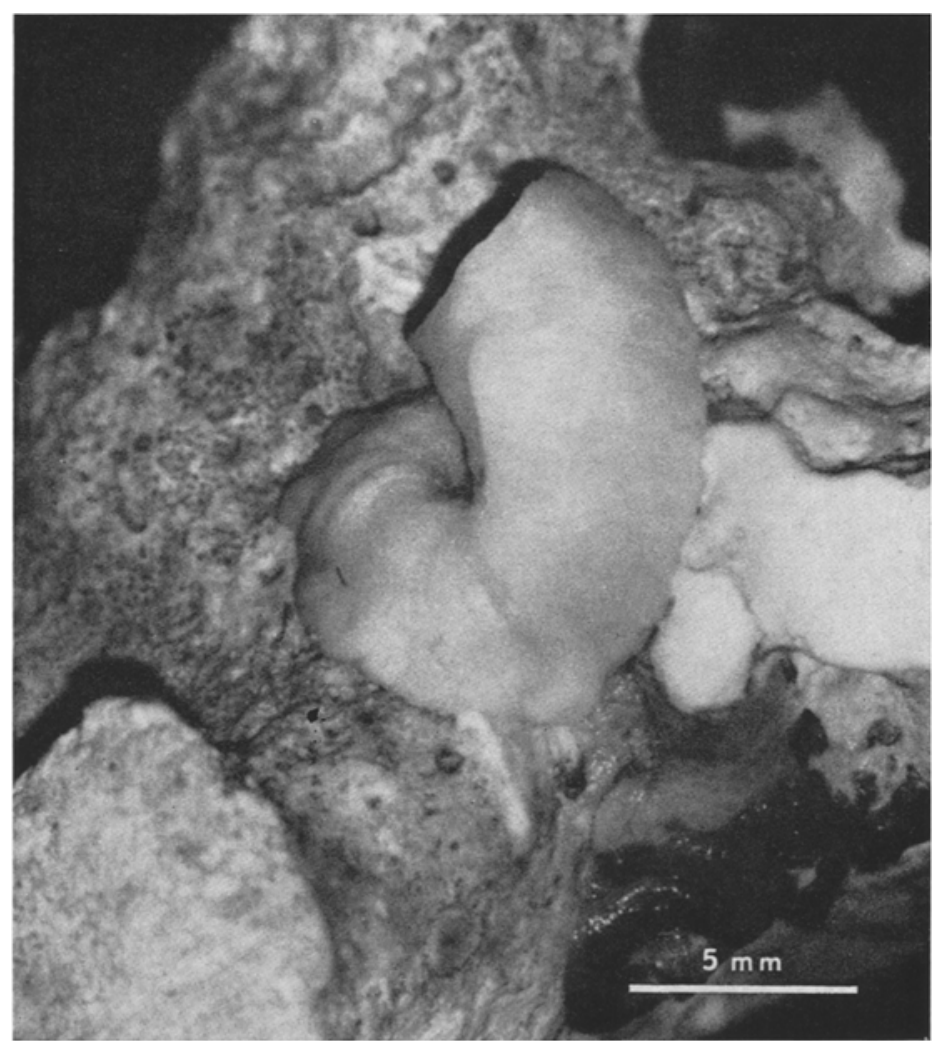

Fig. 5. Dendropoma platypus MoreH, 1861. Typical adult shell

A

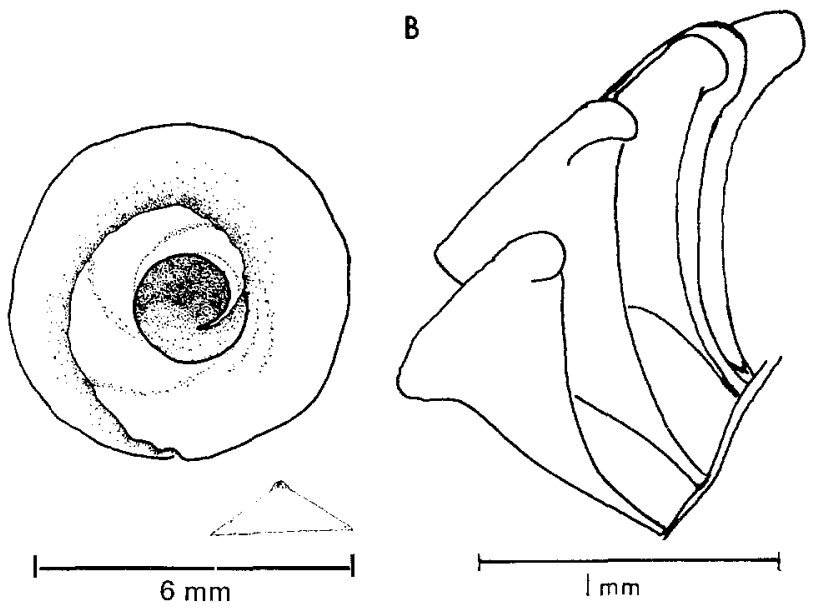

Fig. 6. Dendropoma platypus MIorch, 1861. (A) Operculum showing lateral and ventral views; (B) gill filaments

Habitat and habits. These vermetids are solitary, found usually completely embedded in submerged substrate of coral or shell, or coiled above coral in quiet waters. Dendropoma platypus occurs from the intertidal to depths of $14 \mathrm{~m}$ off Oahu.
Brood protection and larval life. Capsules are brooded in the female mantle cavity, with 5 or more present at one time. The capsules are round, approximately $3 \mathrm{~mm}$ in diameter, and composed of two membranes separated by a layer of gelatinous material 
about $0.25 \mathrm{~mm}$ thick. One capsule may contain over 70 embryos at hatching. A considerable amount of yolk also contained in the capsule is ingested by the developing young. As the embryos develop, the membranes of the capsule become more flaccid, the capsule expands, and the gelatinous material between the capsular membranes seems to disappear.

At hatching, the embryos vary in size and the velar lobes are in varying states of regression. None of the juveniles hatched in the laboratory can swim, and a few have no evident velum. TAYLor (personal communication), however, reports finding larvae of Dendropoma platypus in the plankton in Kaneohe Bay, Oahu: The larval operculum has an orange center and is marked by an orange ring; it is shed after settling. The larval foot is marked with yellow pigment.

Dendropoma psarocephala HADFIELD and KAY, nov. sp. (Figs. 7-9, 19 C)

Type material. Holotype, BPBM (No. 8933). Paratypes: BPBM, USNM. Type locality: subtidally on coralline algal-encrusted reef in Kaneohe Bay, Oahu, Hawaii ( $157^{\circ} 48^{\prime} 13^{\prime \prime} \mathrm{W}$ longitude, $21^{\circ} 26^{\prime} 15^{\prime \prime} \mathrm{N}$ latitude).

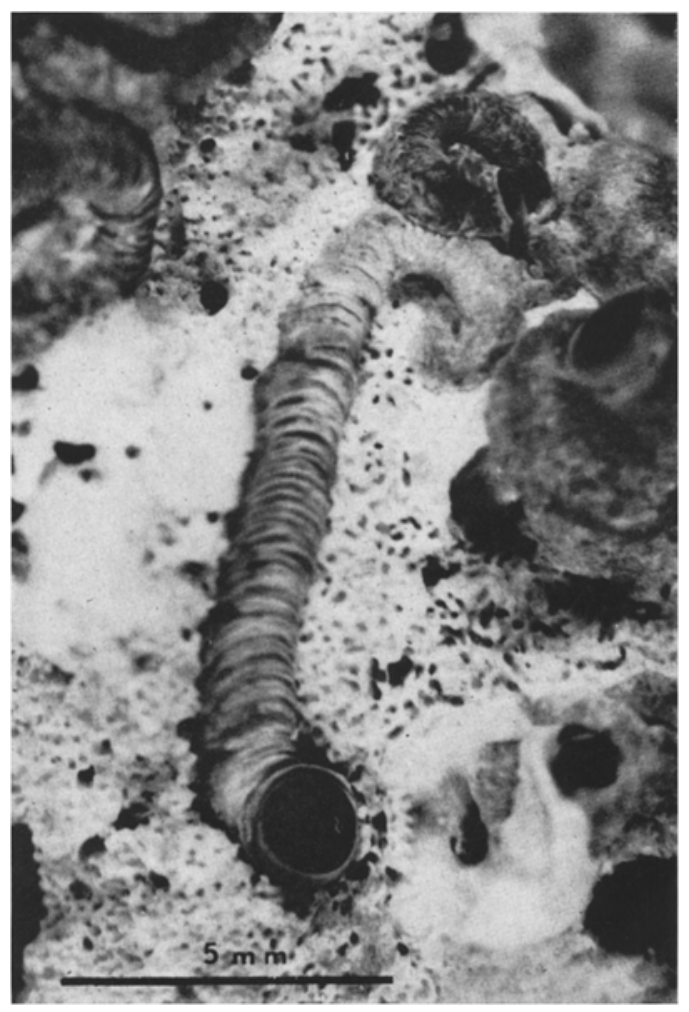

Fig. 7. Dendropoma psarocephala nov. sp. Holotype. Typical darkly colored adult shell with raised, irregularly concentric lamellae
Shell (Figs. 7, 8). Small (maximum tube-diameter $2.5 \mathrm{~mm}$ ); tube deposited in a vertical helical coil, but often conforming to the substrate. Aperture circular, flush with the substrate. Dark purple, with irregular axial riblets which may be developed as laminae on the inner surface of the coil.

Protoconch (Fig. 19C). At hatching, $0.45 \mathrm{~mm}$ by $0.32 \mathrm{~mm}$, of $1 \frac{1}{4}$ to $1 \frac{1}{3}$ whorls; inflated; usually clear and transparent. Ribs weakly developed or absent. Early growth of the teleoconch which is distinctly opaque rose is oriented so that it completely encircles protoconch.

Operculum (Fig. 9). Convex, thick, ranging from button-like to domed in shape. Composed of concentric layers of dark red, chitinous material, sometimes almost black because of thickness of the layers. Pedal surface rimmed by a dark glossy red annulus edged with white and with a white mamilla. Ratio of opercular diameter to aperture $1: 1 \frac{1}{4}$.

Animal. Head and foot black with superficial white spots; rolled edge of mantle collar with tiny black pigment spots diminishing in density distally. Pedal tentacles long and extensible, extending to four times the length of the cephalic tentacles. Mantle margin entire in both sexes. A narrow, ciliated, grooved gutter is present on the right side of the head, emerging from the mantle cavity.

Habitat and habits. These small vermetids are solitary, but settle within one to two millimeters of each other on coralline algal-encrusted coral on fringing and patch reefs at Waikiki, Oahu, and in Kaneohe Bay, Oahu. These vermetids are much shyer than Dendropoma meroclista; they retract into the shell at the least stimulus. Feeding is primarily by mucous threads in the laboratory, but the presence of the feeding gutter on the right side of the head suggests that ciliary feeding mechanisms can be utilized.

Brood protection and larval life. Up to $5 \mathrm{egg}$ capsules have been found in a single brooding female, the capsules arranged in no particular order, are $0.83 \mathrm{~mm}$ in length. From 9 to 23 embryos develop in a single capsule. When the number of developing embryos is large, the double wall of the capsule is stretched as it accommodates them. Intracapsular yolk is contained in packets or platelets of varying sizes; all yolk is consumed by the embryos before hatching.

Except for their smaller size, the hatching young of Dendropoma psarocephala are difficult to distinguish from those of $D$. rhyssoconcha (described below). The hatching embryos have regressing velar lobes. The foot is highly muscular and easily supports the crawling juveniles. Evidence from laboratory observations suggests that $D$. psarocephala is characterized by direct development. Individuals hatched in the laboratory crawl for several days before settling and beginning growth of the teleoconch. The foot of the newly settled snail has white pigment spots. 


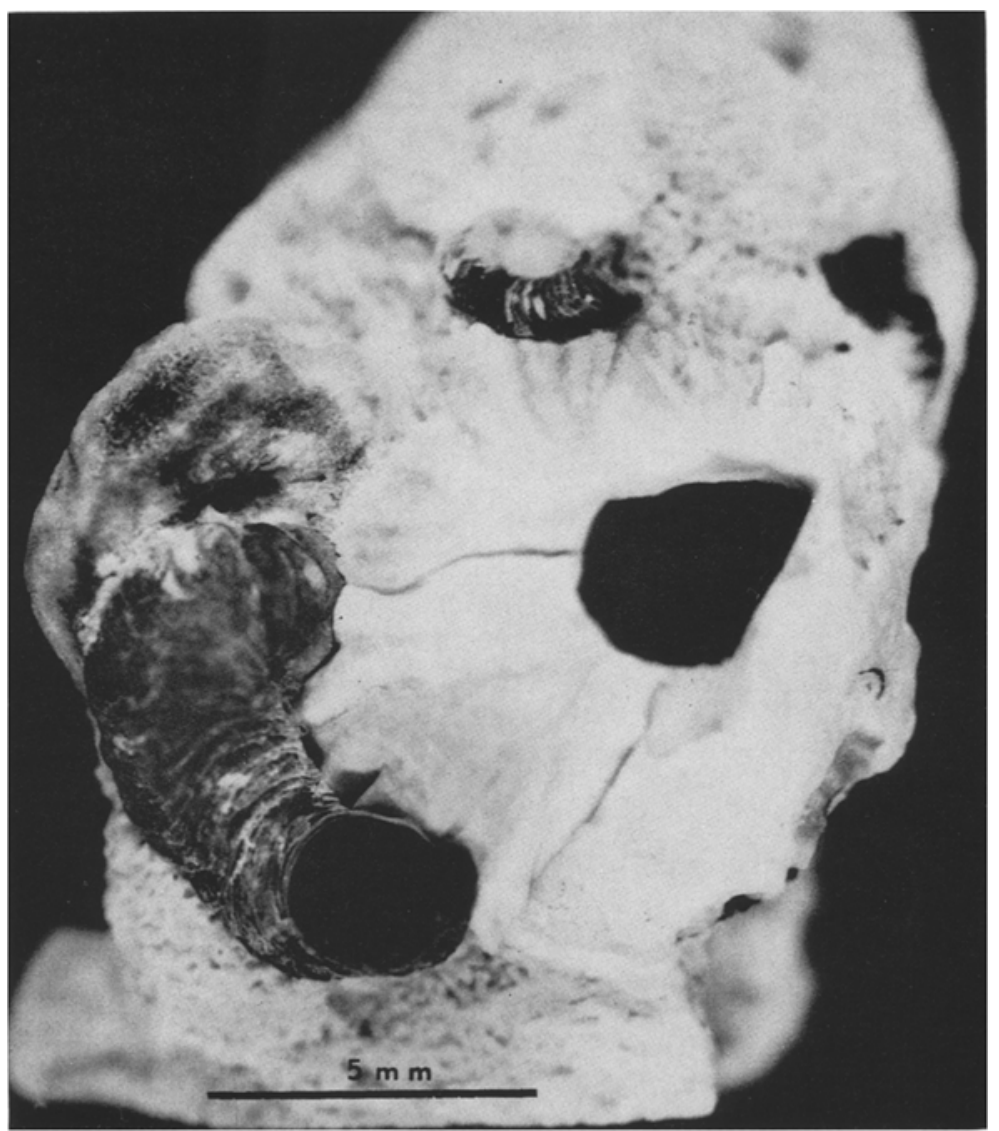

Fig. 8. Dendropoma psarocephala nov. sp. Lightly colored adult shell with irregular, raised lamellae
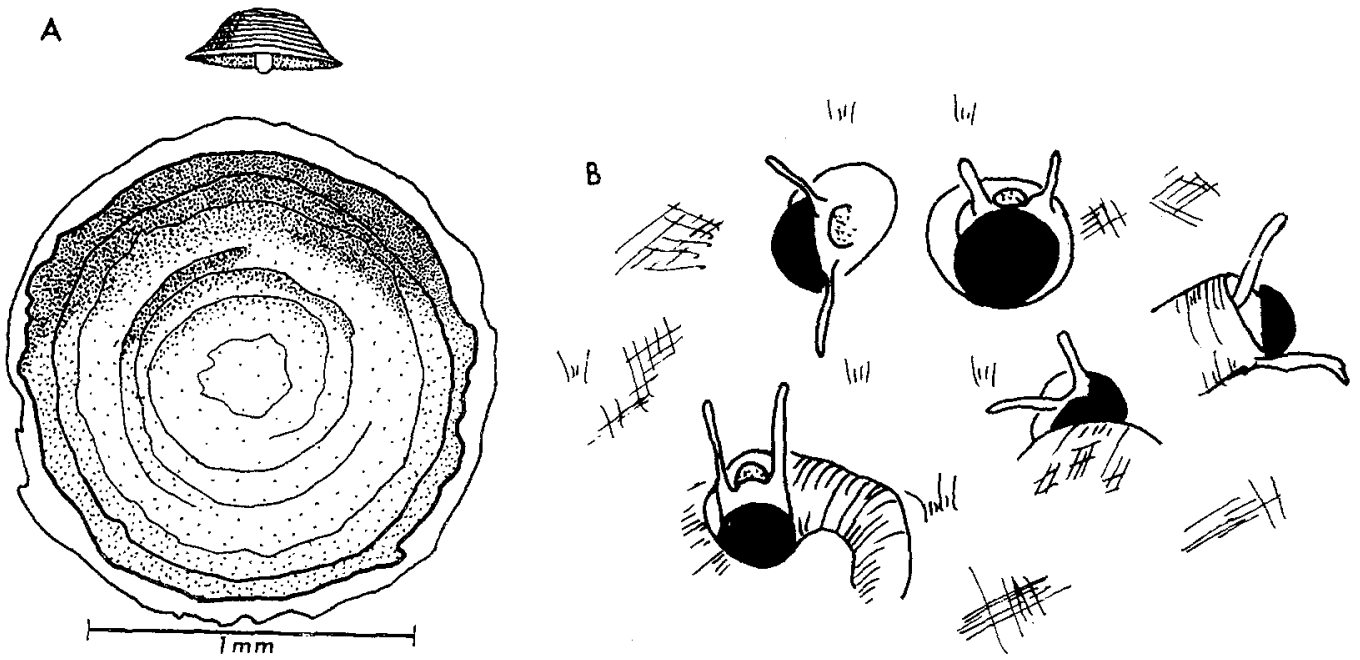

Fig. 9. Dendropoma psarocephala nov. sp. (A) Operculum showing lateral and ventral views; (B) Diagrammatic sketch of the vermetids in situ 


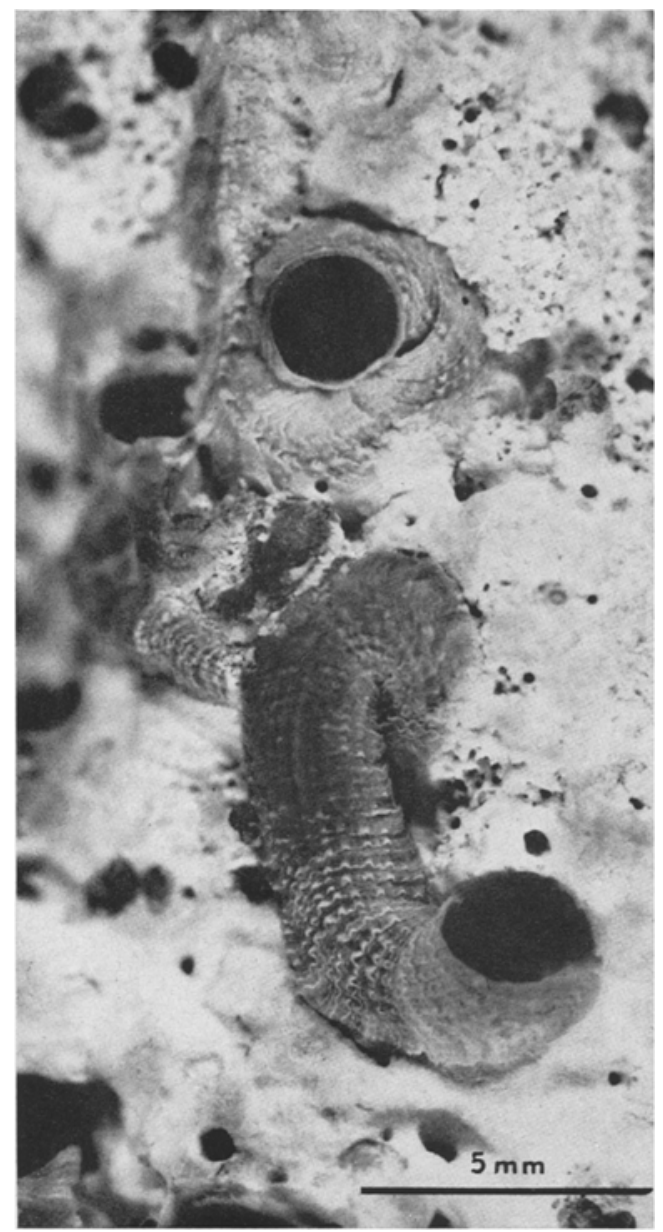

Comparisons. The domed operculum with its eircular marginal rim of Dendropoma psarocephala resembles that of $D$. tholia KEEN and MonTon, 1960 , but the latter species is colonial and encrusting. The dark operculum, animal color and shell configuration distinguish this species from $D$. meroclista. The specifie epithet, from the Greek "speckled head", is descriptive of the animal coloration.

Dendropoma rhyssoconcha HADWIELD and KAY, nov.sp. (Figs. 10-12, 19 E)

Type material. Holotype, BPBM (No. 8935). Paratypes: BPBM, USNM. Type locality: subtidally on coralline algal-encrusted reef in Kaneohe Bay, Oahu, Hawaii $\left(157^{\circ} 48^{\prime} 13^{\prime \prime} \mathrm{W}\right.$ longitude, $21^{\circ} 26^{\prime} 15^{\prime \prime} \mathrm{N}$ latitude).

Shell (Figs. 10, 11). Small (maximum tube-diameter $3.5 \mathrm{~mm}$ ); tube deposited in a vertical helix but often following the contours of the substrate and overgrown with calcareous algae so that only the aperture is exposed. Aperture circular, almost flush with the substrate. Color orange-brown, pink or dark purple. Sculpture of irregular axial ribs on the early teleoconch, becoming scaly axial lamellae which are fluted where crossed by spiral ribs on older portions.

Protoconch (Fig. 19E). At hatching $0.58 \mathrm{~mm}$ by $0.44 \mathrm{~mm}$, of $1 \frac{1}{2}$ whorls, inflated, and with strong axial ribs on the second whorl. Dorsal apertural lip pulled

$\leftarrow$ Fig. 10. Dendropoma rhyssoconcha nov. sp. Holotype. Adult shell with characteristic raised and ruffled lamellae

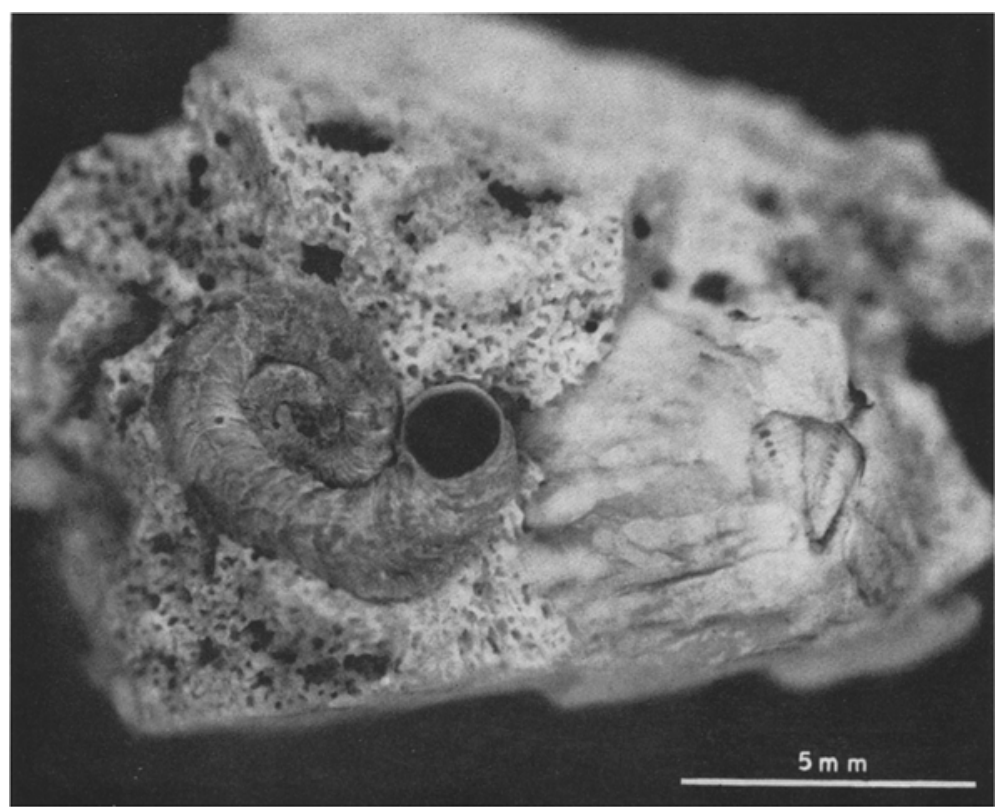

Fig. 11. Dendropoma rhyssoconcha nov. sp. Adult shell with tightly coiling pattern and eroded lamellae 
into a V-shaped beak. Direction of growth of the teleoconch at right angles to that of the protoconch.

Operculum (Fig. 12). Shaped like an inverted cone, the diameter coinciding with that of the aperture; chitinous, translucent and colorless, except for a dark red central spot marking the mamilla on the pedal surface. Occasionally fragile spiral lamellae are seen on the ventral portions.

Animal. Head, foot, mantle and tentacles black, dark green or tan-brown spotted with white or creamyellow; with pale yellow and/or red patches above the eyes; rolled edge of the mantle collar striped by alternating light and dark colors; foot encircling the operculum, red. Pedal tentacles long and extensible. Gill

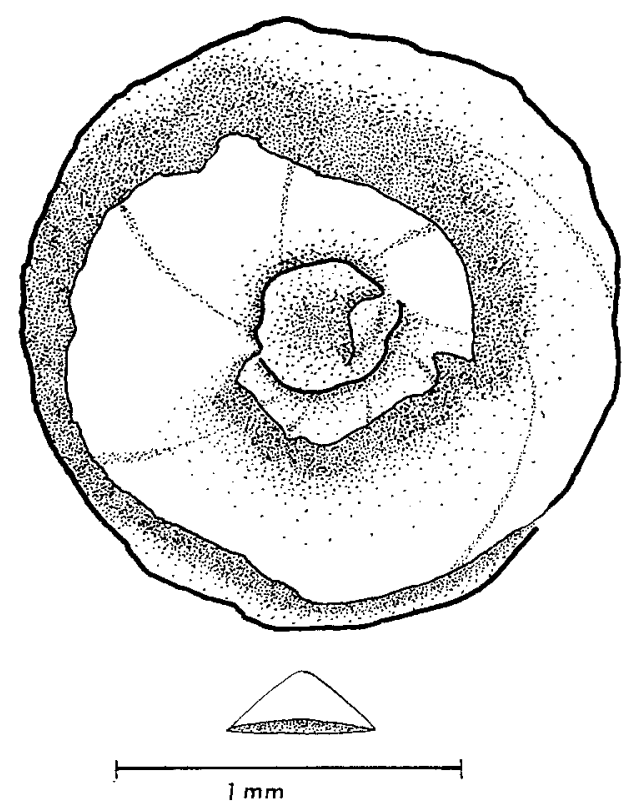

Fig. 12. Dendropoma rhyssoconcha nov. sp. Operculum showing lateral and ventral views

filaments triangular. Mantle margin entire in both sexes.

Habitat and habits. These small vermetids are solitary but settle within 1 to $2 \mathrm{~mm}$ of each other on coralline algal-encrusted coral on fringing and patch reefs in Kaneohe Bay, and Waikiki, Oahu. The operculum is frequently overgrown with calcareous and non-calcareous algae, making field identification difficult. Feeding is by mucous threads. The large operculum and shallow retractor muscle insertion prevent the snail from retracting to any great depth in the shell.

Brood protection and larval life. As many as 6 egg capsules may be brooded concurrently in the mantle cavity. There is no apparent order among the capsules; the oldest capsules are often pushed deep inside the mantle cavity. When 6 capsules are brooded the mantle is stretched and transparent and the female is much restricted in contraction.

The capsules are ovoid, the longest dimension of a young capsule about $2 \mathrm{~mm}$. The number of young per capsule varies from 6 to 25 . As the upper limit of this range is reached, the pre-hatching capsule is found to be so filled with embryonic mass that the doublewalled capsule membrane is stretched, conforming to the bulk it encloses.

Intracapsular nurse yolk develops with the embryos. It is contained in vesicles or platelets of varying size; some apparently are enclosed by membranes. The embryos ingest all of the yolk in the capsule, and the first whorl of the larval shell may be yolk-filled on hatching.

The protoconch is generally colorless, although occasional capsules contain individuals with larval shells which are rose or purple, and less frequently capsules are found with larvae which have a black esophagus. These observations suggest a high degree of genetic variability among brood mates. The larval operculum is marked with an orange center in a transparent disk; it is shed on settling.

At hatching, the velar lobes are in the regressive state and the foot is strong and capable of supporting the crawling, yolk-filled animal. Laboratory evidence strongly indicates that this species is a direct developer. Veligers referable to Dendropoma rhysso. concha have not been recorded in the plankton.

Comparisons. The operculum is unspecialized as it is in Dendropoma marchadi KeEN and MorTon, 1960, but the solitary habit, color of the soft parts, etc. distinguish the Hawaiian species from $D$. marchadi. The specific epithet is from the Greek meaning "wrinkled shell".

\section{Genus Petaloconchus LEA, 1843}

Petaloconchus keenae HADFIELD and $\mathrm{KAY}$, nov. sp. (Figs. 13, 14, 19 G)

Type material. Holotype, BPBM (No. 8937). Paratypes: BPBM, USNM. Type locality: Kaheka (near Koloa), Kauai $\left(159^{\circ} 28^{\prime} 30^{\prime \prime} \mathrm{W}\right.$ longitude, $21^{\circ} 52^{\prime} 30^{\prime \prime} \mathrm{N}$ latitude) on intertidal boulders.

Shell (Fig. 13). Of medium size (diameter of whorls up to $10 \mathrm{~mm}$; apertural diameter, $5 \mathrm{~mm}$ ); early whorls of teleoconch forming a conical coil on the substratum, later whorls emergent and projecting several centimeters above the substratum. Aperture circular. Cream, red-brown, or dark purple, with newly deposited shell of older individuals pale lavender. Sculpture of axial ribs crossed by obsolete striae. Paired internal lamellae, diagnostic of the genus Petaloconchus, in the area of attachment of the columellar muscle and extending to the tip of the gonad; each lamella projects into the lumen of the tube at a slightly ventro-lateral posi- 

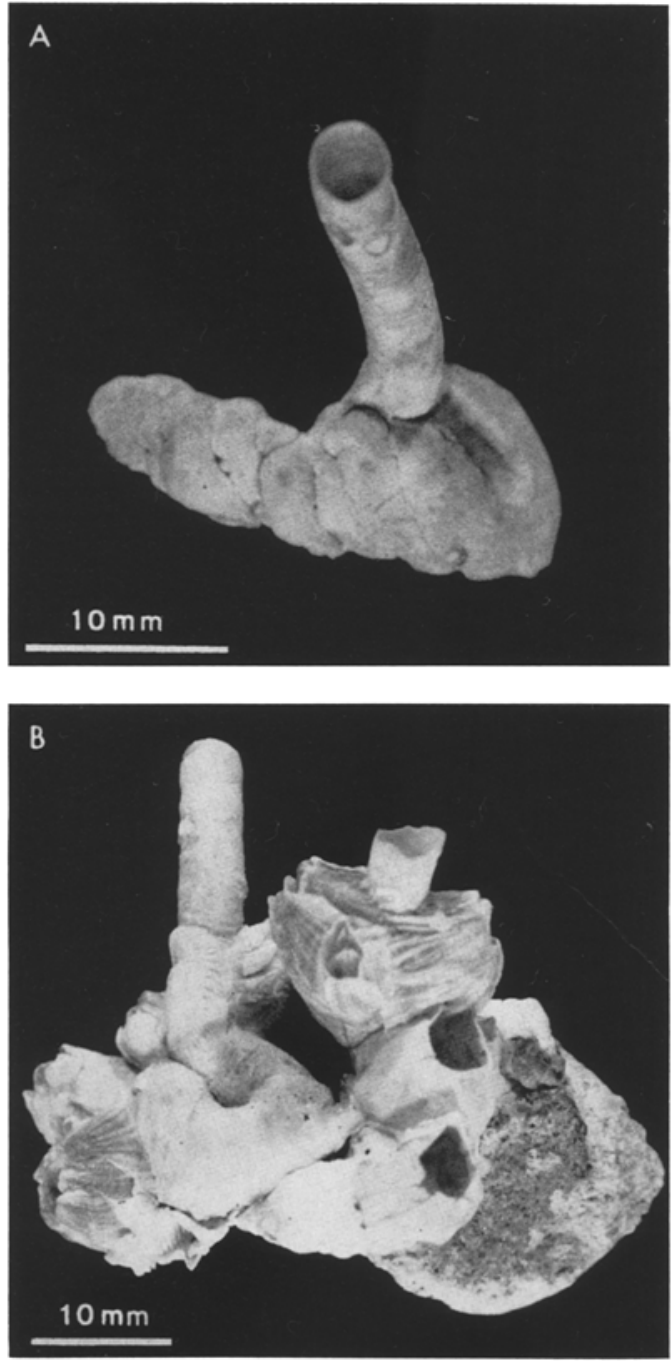

Fig. 13. Petaloconchus keenae nov. sp. (A) Typically coiled adult shell as seen on smooth surfaces; (B) irregularly coiled adult shell

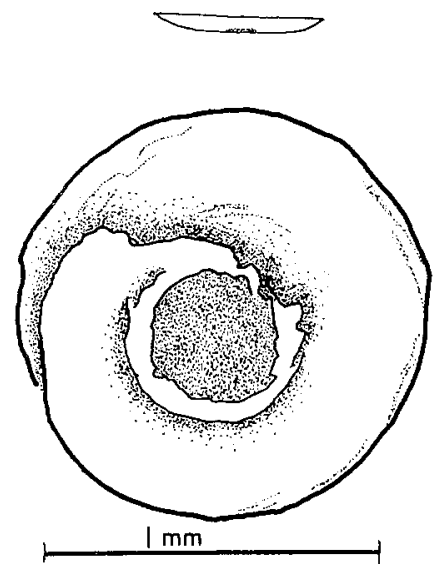

Fig. 14. Petaloconchus keenae nov. sp. Operculum showing lateral and ventral views tion to a depth of one-third of the shell diameter. In this region there is also a low medio-ventral ridge which appears to mark the site of the retractor muscle attachment.

Protoconch (Fig. 19G). At hatching $0.7 \mathrm{~mm}$ by $0.45 \mathrm{~mm}$, of $2 \frac{1}{2}$ or 3 whorls; cylindrical; suture redbrown.

Operculum (Fig. 14A). Slightly concave, with a thickened and raised (convex) black center and a small mamilla on the pedal surface; chitinous, thin and transparent. Pedal gland visible as a white crescent through the center. About one-third the diameter of the aperture.

Animal. Head, foot, tentacles and mantle handsomely pigmented dark purple to rosy brown, sprinkled with white dots and with yellow, especially in older individuals, on the rolled edges of the mantle. Metapodial region of foot consisting of a raised, grooved pad rising medially back of the operculum and terminating in a scalloped shelf at the border of the pedal tentacles. Pedal tentacles long and extensible, about two times the length of the cephalics. Mantle margin slit in females. Ctenidium occupying the length of the mantle cavity; gill filaments narrow and elongate, barely extending to the mid-line of the mantle cavity (Fig. 14B). Osphradium light brown, elongate. Pedal gland small, approximately one-quarter the diameter of the foot. Columellar muscle long and strap-like, attached to fally one-half of the visceral coil.

Habitat and habits. This is the most common and ubiquitous vermetid in the Hawaiian Islands, occurring intertidally and subtidally wherever there is suitable substrate. It is the dominant species on coralline algal-covered surfaces of patch reefs in $\mathrm{Ka}$ neohe Bay, Oahu, and forms finger-like protruberances in coral in subtidal coral communities. Petaloconchus keenae feeds by both ciliary means and by mucous threads.

Brood protection and larval life. The ovoid capsules, each about $2 \mathrm{~mm}$ in length, are suspended in the mantle cavity by a slender stalk attached to the shell. Each capsule contains from 17 to 30 eggs, each about $217 \mu$ in diameter, plus a large amount of nurse yolk. The hatching larvae vary in size having shells of $2 \frac{1}{2}$ to 3 whorls which, at the largest, measure 0.70 by $0.45 \mathrm{~mm}$. Early veligers have a purplish-black esophagus; later larvae develop a distinctive red-orange coloration in the ventral lobe of the digestive gland. Most post-hatching larvae seem incapable of swimming; they crawl for a short time and then cement the shell to a substratum. J. TAYLOR (personal communication) has, however, recorded these larvae in the plankton of Kaneohe Bay, Oahu.

Comparisons. This species is named for Dr. A. M. KEEN who has contributed, among other things, so much to untangling the complexities of vermetid taxonomy. 
Genus Serpulorbis Sassi, 1827

Serpulorbis variabilis HADFIELD and $\mathrm{KaX}$, nov. sp. (Figs. 15, 16, 19 B)

Type material. Holotype, BPBM (No. 8939). Paratypes: BPBM, USNM. Type locality: Kaheka (near Koloa), Kauai $\left(159^{\circ} 28^{\prime} 30^{\prime \prime} \mathrm{W}\right.$ longitude, $21^{\circ} 52^{\prime} 30^{\prime \prime} \mathrm{N}$ latitude) on an intertidal water-levelled bench.

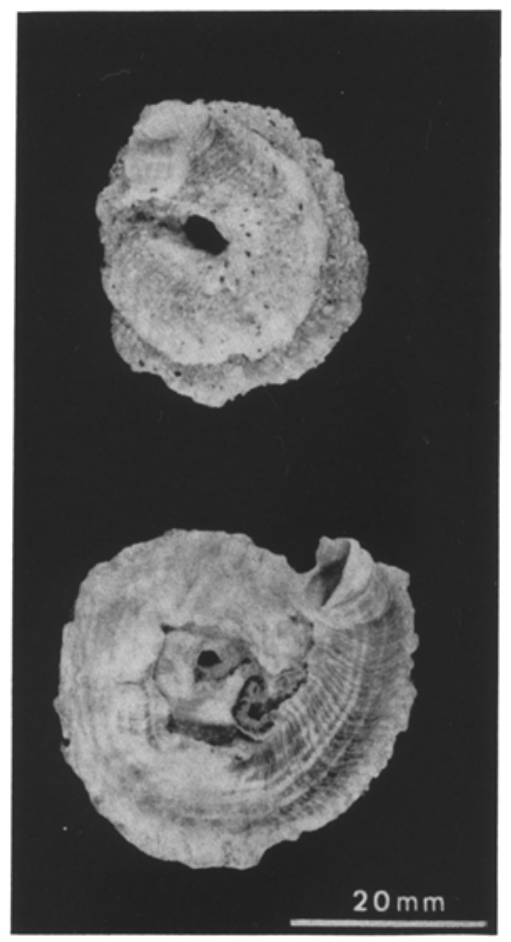

Fig. 15. Serpulorbis variabilis nov. sp. Two adult shells, upper with partly closed coil, lower with more typical open coil. Note small tube of Dendropoma psarocephala on lower coil

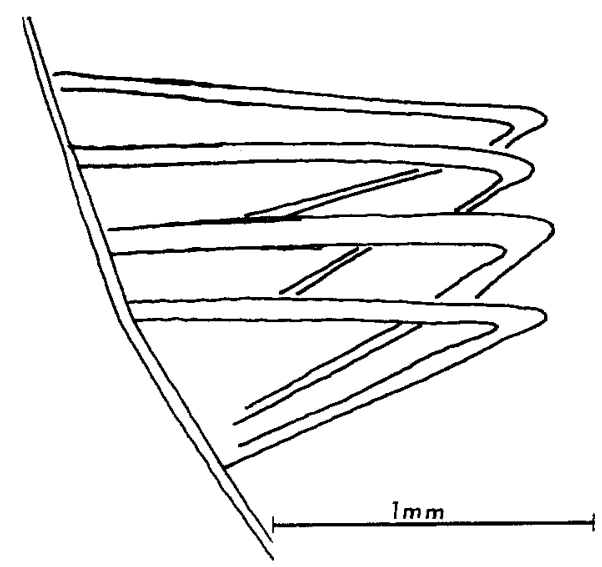

Fig. 16. Serpulorbis variabilis nov. sp. Diagrammatic sketch of gill filaments
Shell (Fig. 15). Large (whorls not exceeding $40 \mathrm{~mm}$ in diameter; apertural diameter $7 \mathrm{~mm}$ to $9 \mathrm{~mm}$ ). Tube deposited in a single, flat, planorboid coil, hollow in the center or filled by an earlier whorl. Aperture circular when tubes are raised from substrate or with adherent corners when completely attached to substrate. Externally white or white-tan, sometimes mottled with irregular darker streaks; interior nacreous white and light brown. Sculpture of heavy axial ribbing running the length of the tube, with about four ribs; spiral ribs crossing the axial ribs heavy to fine.

Protoconch (Fig. 19 B). At hatching, $0.27 \mathrm{~mm}$ by $0.12 \mathrm{~mm}$, of $1 \frac{1}{2}$ whorls, in the shape of a broadbased, inflated cone; brown.

Animal. Color variable; head, foot, cephalic and pedal tentacles and mantle usually mottled orange, white and yellow, or bright red or brown with white and yellow; some individuals predominantly brown, others bright orange. Metapodial plug translucent white with opaque white and brown spots, the spots often rising as distinct tubercles; foot margined with alternating brown and white spots. Mantle margin lining tube and mantle cavity forming a long, free tube into which the snail's head and foot contract. Pedal tentacles extremely long and extensible; cephalic tentacles short and truncate. Mantle margin in females deeply incised for two-thirds of the mantle cavity. Gill filaments straight-sided triangles, barely extending to the mid-point of the mantle cavity. Pedal mucous gland compact, about balf the diameter of the foot.

Habitat and habits. Serpulorbis variabilis is a commonly occurring vermetid on intertidal solution benches on Kauai, Oahu, Maui and Hawaii, at the seaward edge of tidepools, and subtidally to depths of $14 \mathrm{~m}$. These vermetids often form a narrow band on boulder surfaces at the 0.0 tide level.

The character and texture of the shell vary with habitat: animals from pools and erevices (such as at Sandy Beach, Oahu and Poipu, Kauai) have thick shells heavily encrusted with coralline algae, terminating in raised tubes, and with circular apertures. Snails found on intertidal benches have shells which are almost completely attached, and the aperture is usually drawn out at the corners. The external surface of the shell is frequently obscured by a heary layer of adherent sand grains.

Animal color varies as much as shell shape and the variation is apparently genetic as it does not correlate with size, sex or habitat.

Serpulorbis variabilis feeds both by mucous threads and by ciliary means. The snails are easily recognized in the field by the dense web of mucous threads which covers the aperture.

Brood protection and larval life. The egg capsules are elongate. They hang by short stalks in a long row in the female's mantle cavity, passing through the 
slit in the dorsal margin. Females may brood as many as 48 capsules at one time. The eggs are usually bright green, although occasional females are found with light yellow eggs. As the young develop, the color within the capsules pales and then changes to brown.

Single capsules contain as many as 240 eggs, each approximately $190 \mu$ in diameter. At least some of the eggs serve as nurse yolk. The largest number of welldeveloped larvae seen in one capsule was 190; other capsules with late larvae contained as few as 59 individuals.

Juveniles of Serpulorbis variabilis hatch as small planktonic veligers. The velum is a simple, bilobed structure. The larvae apparently spend several weeks in the plankton.

Comparisons. The name variabitis is chosen because of the variation in shell and color characters of the species.

\section{Genus Vermetus Daudin, 1800}

Vermetus alii HADFIELD and $\mathrm{K}_{A Y}$, nov. sp. (Figs. 17, 18, 19 D)

Type material. Holotype, BPBM (No. 8941). Paratypes: BPBM, USNM. Type locality: Mokuoloe (Coconut Island), Kaneohe Bay, Oahu, Hawaii (157 $48^{\prime} 10^{\prime \prime} \mathrm{W}$ longitude, $21^{\circ} 26^{\prime} 10^{\prime \prime} \mathrm{N}$ latitude) on subtidal coral.

Shell (Fig. 17). Of medium to large size (diameter of whorls up to $35 \mathrm{~mm}$; maximum apertural diameter, $8 \mathrm{~mm}$ ). In loose coils which may be planorboid but with the distal end often rising several centimeters above the substrate. Aperture circular. Exterior white with brown streaks; interior white smudged with brown. Sculpture on earlier whorls of strong axial ribs intersecting and producing a regularly cancellate pattern; later parts of the shell with fine, raised threads.

Protoconch (Fig. 19 D). At hatching, $0.42 \mathrm{~mm}$ by $0.35 \mathrm{~mm}$, of two whorls; cylindrical; transparent or brown-tan with darker sutures.

Operculum (Fig. 18). Concave with a large, flat central disk attached to the foot. Peripheral portions translucent amber with acute spirale lamellae. Ratio of opercular diameter to tube $1: 2$.

Animal. Head, foot, tentacles and mantle purplered shading to rose at the edges and toward the neck, spotted with white; posteroventral portion of foot brown-yellow; edge of mantle collar yellow, grading from dark purple to rose posteriorly. Metapodial region of foot consisting of a raised, grooved, sole-like plate terminating in a scalloped shelf at the base of the pedal tentacles. Pedal tentacles short relative to the cephalies. Mantle margin entire in both sexes. Ctendium occupying the length of the mantle cavity, with elongate, club-shaped gill filaments extending about one-third the diameter of the mantle cavity. Osphradium a prominent, coiled structure with a broad, white
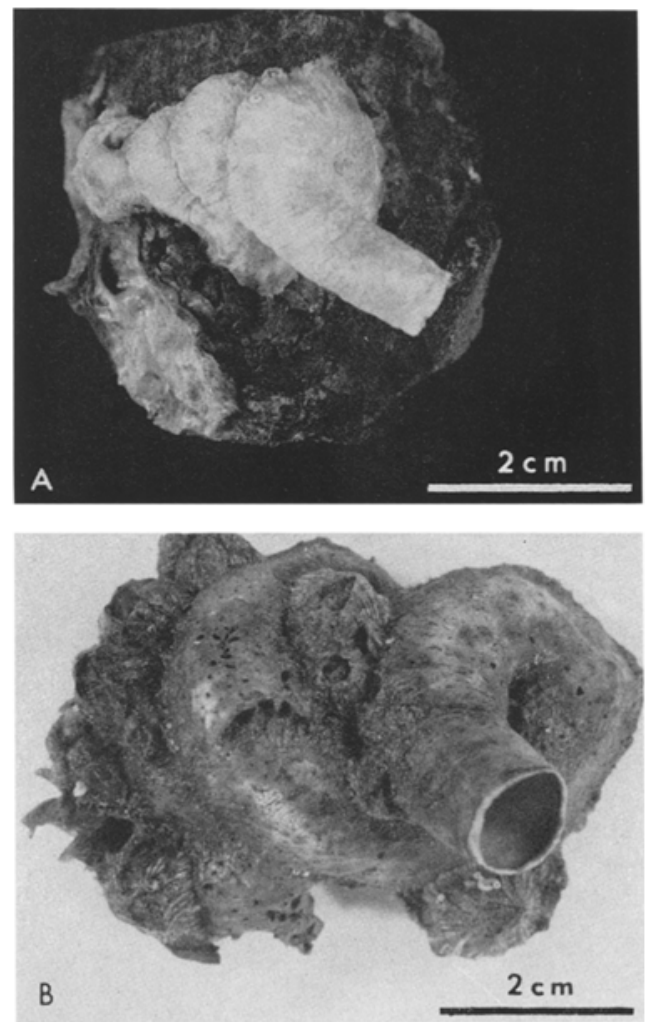

Fig. 17. Vermetus alii nov. sp. (A) Cleaned adult shell; (B) typically darkly colored shell of living adult

A
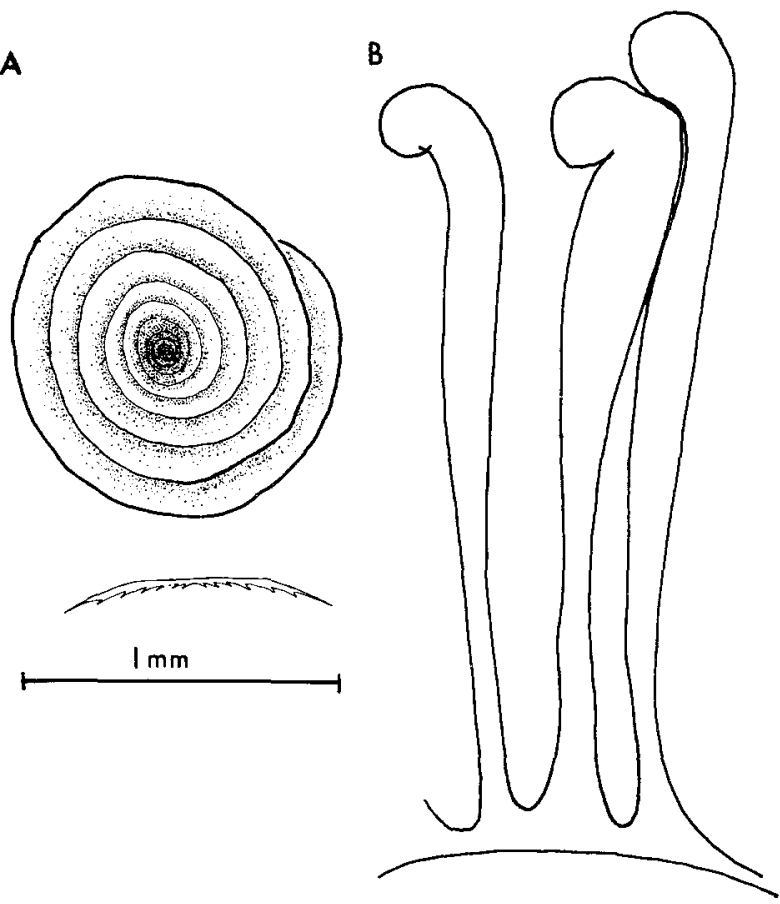

Fig. 18. Vermetus alii nov. sp. (A) Operculum showing lateral and ventral views; (B) diagrammatic sketch of gill filaments 

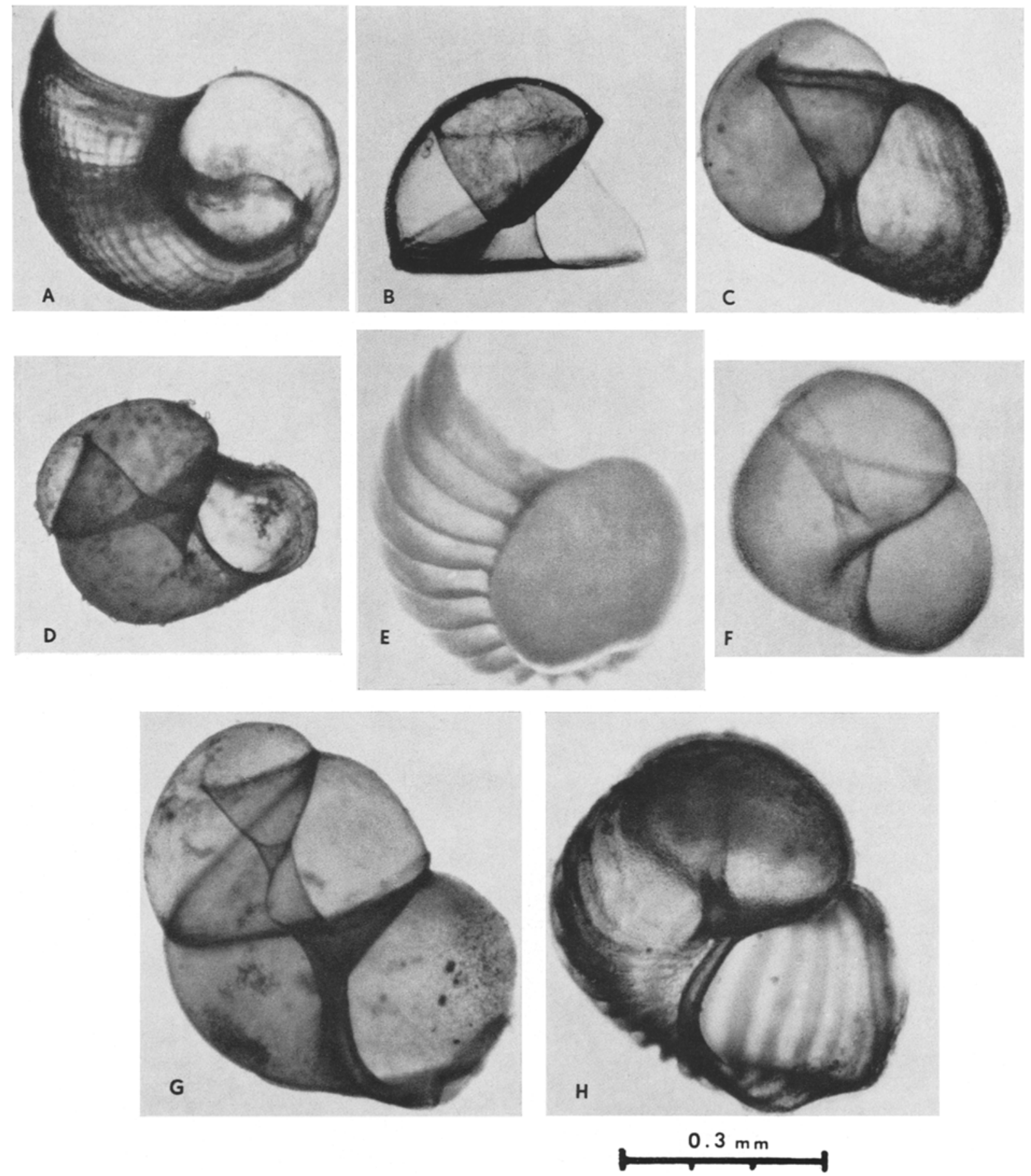

Fig. 19. Hawaiian Vermetidae. Protoconchs. (A) Dendropoma gregaria nov. sp.; (B) Serpulorbis variabilis nov. sp.; (C) Dendropoma psarocephala nov. sp.; (D) Vermetus alii nov. sp.; (E) Dendropoma rhyssoconcha nov. sp.; (F) Dendropoma meroclista nov. sp.; (G) Petaloconchus keenae nov. sp.; (H) Dendropoma platypus MörcH, 1861. These are the shells of hatching larvae or juveniles and are distinguished from the protoconchs of adult shells which display the considerable growth occurring during the planktonic period, especially in S. variabilis and V. alii 
endostylar region at the base of the gill. Pedal gland small, about one-quarter the diameter of the foot.

Habitat and habits. This is the largest species of Hawaiian vermetid, occurring intertidally and subtidally cemented to coral heads and concrete sea walls such as those in the docks at Mokuoloe Island (Coconut Island), Kaneohe Bay, Oahu. The shell is usually overgrown by algae which obscure the color and sculpture of the teleoconch. In the laboratory these vermetids have been observed to cut back the ventral half of the tube to a depth of $15 \mathrm{~mm}$ by radular action. The shell is then laid down in a new direction, presumably adjusting to currents in the water tank, and the result is a "feeding tube" (KEEN, 1961) which is formed from the bit of old shell remaining.

Brood protection and larval life. As many as 50 ovoid egg capsules, $2.3 \mathrm{~mm}$ in length, may be brooded at one time in the mantle cavity. During embryonic growth the capsules swell and become nearly round. Each capsule may contain from 80 to 200 embryos plus a considerable amount of nurse yolk which is ingested during the course of larval growth. The clearly planktonic veligers add nearly a complete whorl to the protoconch before settling.

Vermetus alii feeds primarily by ciliary means. A distinctly ridged, ciliated groove is present on the right side of the head, and a large, rather liquid bolus of mucus is almost constantly emitted along it.

Comparisons. The term "alii" is the Hawaiian word for chief or royalty and was chosen as the specific epithet because of the large size and purple and yellow coloration of the species.

\section{Relationships of the Hawaiian vermetids}

We have followed KEEN (1961) and MorTon (1965) in recognizing four main vermetid genera: Dendropoma, distinguished by entrenching shells and elaborate opercula which fill the tube and bear an axial mamilla; Petaloconchus, with an internal lamella and a small, concave operculum ; Serpulorbis, which is nonoperculate with a brightly colored, large and extensible foot; and Vermetus, which resembles Petaloconchus with its small operculum but which lacks the internal lamella of the shell of that genus.

Anatomically vermetid genera are not so easily distinguished, although the short columellar muscle of Dendropoma, the long slender columellar muscle and gonadial tail of Petaloconchus, and the flexible foot and elongate mantle cavity of Serpulorbis appear to be characteristic of the genera (MorTon, 1965). The form of the foot may also be characteristic of the genera: in Dendropoma the mesopodial region immediately posterior to the operculum is a flattened hump, while in Petaloconchus, Serpulorbis, and Vermetus it is a pedestal-like structure, variously scalloped around the opening of the pedal gland.
Other features of vermetids such as the radula, split or entire mantle margin in females, type of brood protection, length of the pedal tentacles relative to the cephalics, size of the pedal gland, and the shape of the gill filaments apparently cross generic lines. We have examined the radulae of all the species discussed and must agree with MorTon (1965) "The radula is a very conservative structure within the family Vermetidae.". One sees very little difference between the radulae of species, even between genera. However, contrary to MorTon's (1965) statements that the female mantle cavity is entire in Dendropoma and Petaloconchus but split in Vermetus, and that the pedal tentacles in Dendropoma are short, we find that the mantle in the females is split in Dendropoma meroctista and in Petaloconchus keenae but entire in Vermetus alii, and that all five species of Dendropoma have long, flexible pedal tentacles utilized in mucous-thread feeding.

The size of the pedal gland relative to the foot, the extensibility of the pedal tentacles, and the shape of the gill filaments are apparently associated with feeding habits, those vermetids with a small pedal gland, elongate gill filaments and large buccal mass relative to the head, feed primarily by ciliary means, while those with a large pedal gland, triangular gill filaments, and a small buccal mass are predominantly mucous thread feeders. Mon'on (1965), however, points out that ciliary and mucous thread feeding are not mutually exclusive and, indeed, we have observed both types of feeding occurring simultaneously in four of the Hawaiian vermetids.

\section{Methods of feeding}

Among the Hawaiian vermetids, ciliary feeding appears to predominate only in Vermetus alii, and the large buccal mass, small pedal gland, and elongate gill filaments in this species simulate those of the predominantly ciliary-feeding Dendropoma maxima of the Great Barrier Reef (see YoNGE, 1932). There is a noticeable inhalent current on the left side of the mantle cavity, copious production of mucus in the mantle cavity, and a large, relatively fluid mucous mass is almost constantly emitted on the right side of the head. Mucous threads, when they are produced, appear in the same manner as do those in Dendropoma, Petaloconchus, and Serpulorbis described below.

The five species of Dendropoma and Serpulorbis variabilis have triangular gill plates, a large mucous gland relative to the size of the foot, small buccal mass relative to the size of the head, and long and extensible pedal tentacles. Petaloconchus keenae differs only in its elongate rather than triangular gill filaments. Although ciliary feeding was observed to occur in all of the species, mucous thread feeding appears to predominate in nature. In Dendropoma spp., feeding is initiated when the pedal tentacles are extended upward and beyond the edge of the shell, projecting over the 
metapodium. As they are extended, the pedal tentacles make abrupt, flicking motions and small droplets of mucus are spun off the tips, the droplets becoming drawn out as fine threads which attach to epiphytes and raised portions of the substrate surrounding the shell. As the mucous threads become laden with diatoms, sand grains, shell fragments, and detritus, the pedal tentacles retract, passing over the metapodial region of the foot and breaking off the stream of mucus which has been issuing from them. With the pedal tentacles retracted, the head is protruded, the jaws and radula grasp one or more of the threads and the food-laden mucus is ingested. Feeding by mucous threads is rhythmical, selective, and apparently stimulated by water currents. In Dendropoma meroclista the feeding sequence averaged $1.5 \mathrm{~min}$ in mucous thread spinning, $5 \mathrm{sec}$ in retraction, and $1 \mathrm{~min}$ in ingestion. Fecal pellets, shell fragments, and particles more than $2 \mathrm{~mm}$ in diameter were rejected, the radula grasping the particle-laden threads and shearing them off. Quiescent vermetids were stimulated to feed by puffing water currents from a pipette over the substrate.

Mucous thread feeding is similar in Petaloconchus keenae, Serpulorbis variabilis, and Vermetus alii with these differences: in Serpulorbis and Vermetus the movements of the extending pedal tentacles are slower and less abrupt than in Dendropoma spp., and in Serpulorbis the mucous threads may form a dense network across the tube aperture rather than a net several millimeters from the tube.

It has been suggested (see YoNGE and ILes, 1939; Morton, 1965) that there is an ecological correlation with the mode of feeding, ciliary feeding as in Dendropoma maxima being perhaps best developed in exposed situations with continually broken waters and wave disturbance where mucous traps might be difficult to put out and maintain successfully. Among the Hawaiian vermetids, the only predominantly ciliary feeder, Vermetus alii, occurs in quiet waters (see below), and Serpulorbis variabilis and Dendropoma platypus, both of which produce conspicuous mucous nets, are often found in surf-beaten areas. The small species of Dendropoma also occur on the outer faces of reefs where there is considerable wave action.

\section{Distribution and ahundance}

Vermetids have been recorded as primary collaborators in forming organic substrates in the Cape Verde Islands (Crossland, 1905), along the Mediterranean shore of Israel (SAFriel, 1966), and along the coastline of Brazil (KEMPF and LABOREL, 1968); as indicator organisms in intertidal communities in New Zealand (Cranwell and Moore, 1938); and as intertidal zone formers in Bermuda and Lower California (Stephenson and Stephenson, 1954; Keen, 1960).
Densities as high as $100,000 / \mathrm{m}^{2}$ for Petaloconchus montereyensis in California have been caleulated (HADFIELD, 1970).

Five vermetids are characteristic of intertidal areas in the Hawaiian Islands. Dendropoma gregaria, which is highly gregarious, is the only intertidal zone former, veneering solution and water-levelled benches and projecting boulders in these areas, and in tidepools, with a mat several centimeters in thickness. Densities of $D$. gregaria on a water-levelled bench at Diamond Head, Oahu were estimated at $60,000 / \mathrm{m}^{2}$. Four solitary species also occur in the intertidal zone, their distribution apparently associated with the degree of wave action. Serpulorbis variabilis is found at the outer edges of intertidal benches and tidepools and on the vertical faces of lava boulders, all areas where wave action is severe. The distribution of $D$. platypus, Petaloconchus keenxe, and Vermetus alii in three intertidal areas at Mokuoloe (Coconut Island) in Kaneohe Bay, Oahu, is shown in Fig. 20, and the species composition of the vermetids in an adjacent subtidal area is shown for contrast. The substrate of the south dock wall is concrete and the only movement of water in the dock area is that due to the rise and fall of the tides; the channel reef is calcareous, algal-covered coral, which receives slight-to-moderate wave action. Fig. 20 indicates the dominance of $V$. alii in quiet waters and of $D$. platypus where there is some wave action. $P$. keenae forms from 35 to $45 \%$ of the vermetids in both areas, but becomes the dominant form on Porites subtidally. Maximum densities observed in these areas were 350 vermetids $/ \mathrm{m}^{2}$ on the wall of the dock and $590 / \mathrm{m}^{2}$ on the Porites at the base of the wall.

The distribution and abundance of four reefassociated vermetids were studied on Checker Reef, a subtidal patch reef northwest of Mokuoloe (Coconut Island) in Kaneohe Bay, Oahu during the summer of 1968. The study area extended approximately $200 \mathrm{~m}$ along the northwest periphery of the reef, 4 to $10 \mathrm{~m}$ across the surface, and $6 \mathrm{~m}$ down the reef slope. The reef slope is comprised principally of living coral such as Porites, Montipora, and Pocillopora, and masses of the green alga Dictyosphcieria. At the tidal edge of the slope, a 4 to $5 \mathrm{~m}$ band of coralline algal-covered substrate borders the reef surface; it is succeeded by a 2 to $3 \mathrm{~m}$ band of dead coral-heads (ca. 150 to $350 \mathrm{~cm}^{3}$ ), a 2 to $3 \mathrm{~m}$ band of smaller coral rubble (ca. 25 to $100 \mathrm{~cm}^{3}$ ), and finally by the silty sand of the interior reef flat. The bases and non-living portions of the corals of the reef slope, and the dead coral heads and rubble on the reef surface are covered by calcareous algae. Five substrate types, coralline algal ridge, Porites, dead coral-heads, coral rubble, and Dictyosphaeria, were selected for quantitative examination, with quadrats of $0.25 \mathrm{~m}^{2}$ examined both visually in the field and by removing several to the laboratory for examination with a dissecting microscope. The species 
composition of three (coralline algal-ridge, dead coralheads, and Porites) is shown in Fig. 20.

The reef-associated vermetids occur most abundantly on coralline algal-covered substrates, with densities as high as $13,000 / \mathrm{m}^{2}$ estimated on the coralline algal-ridge of the reef surface. Maximum densities of 1800 vermetids $/ \mathrm{m}^{2}$ were found on the dead coralheads and $500 / \mathrm{m}^{2}$ on the bases of Porites on the reef slope. There appeared to be fewer individuals on coral rubble of all sizes, especially when it was covered with silt or filamentous green algae than on otherwise similar, adjacent substrates. No vermetids were found in 30 quadrats of Dictyosphaeria, but, in surveys of the study area, three Petaloconchus keence were found attached to the hard substrate beneath and growing through the alga. Significantly more P. keenae were coralline algal-covered substrates, and generally represented 20 to $30 \%$ of the vermetids found on the reef (Fig. 20).

\section{Reproductive biology}

There are good indications that the Hawaiian vermetids all reproduce throughout the year. While we have collected females of all species brooding eggs and embryos in every season, Serpulorbis variabilis undoubtedly has a broad peak of more intense reproductive activity during the summer months.

The wide range of developmental patterns in the Vermetidae remains enigmatic. Egg size does not correlate particularly well with directness of development. Serpulorbis variabilis and Vermetus alii (see Table 1) produce smaller eggs, around $200 \mu$ in diam-

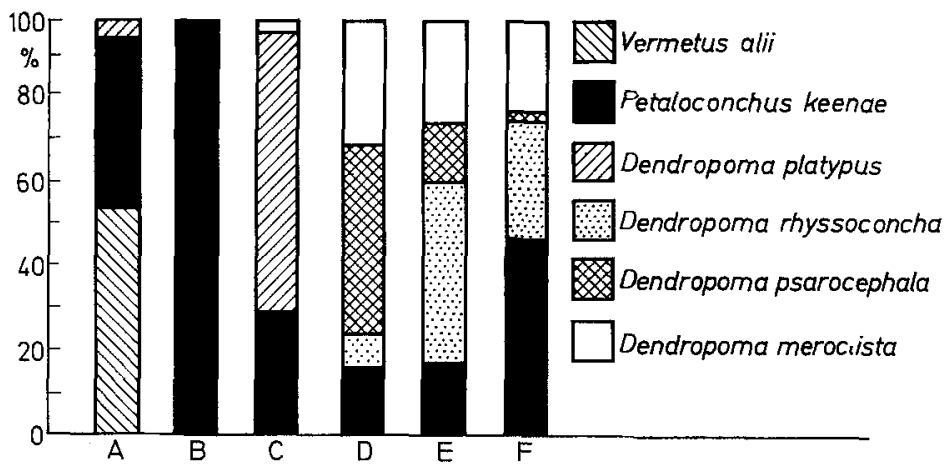

Fig. 20. Hawaiian Vermetidae. Species composition in intertidal zone and on patch reef. $A$ : Dock wall at Mokuoloe (Coconut) Island; $B$ : subtidal Porites below dock; $O$ : Channel Reef at Mokuoloe (Coconut) Island; $D$ : algal ridge at Checker Reef; $E$ : dead coral and rubble at Checker Reef; $F$ : Porites at Checker Reef

found at the reef edge than on the coralline algalridge ( $\mathrm{P}<0.001$, ManN-WhITNey $\mathrm{U}$ test $)$ and similar but non-significant trends were indicated for Porites and dead coral heads.

Petaloconchus keenae was most abundant on coralline algal-covered substrates, and it was the most generally distributed of the vermetids with respect to substrate, occurring at least occasionally on all substrates examined, including corals such as Montipora and Pavona. It was the dominant species on Porites, but represented only 16 to $18 \%$ of the vermetids on the coralline algal-ridge (Fig. 20).

Densities of Dendropoma rhyssoconcha were similar on dead coral heads and on the coralline algal ridge, representing $40 \%$ of all the vermetids found on the rubble but less than $10 \%$ of those on the coralline algal-ridge. It was occasionally found on the live portions of Porites, Montipora, and Pavona. Dendropoma psarocephala was the dominant species on the coralline algal-ridge, showed a markedly decreased abundance on rubble, and was rare on the bases of Porites. Dendropoma meroclista appeared to be restricted to. eter, which develop to pelagic, planktotrophic larvae, while Petaloconchus keenae, with eggs in the same size range, may produce the largest, directly-developed juveniles known in the Hawaiian vermetid fauna. The Dendropoma species, with egg sizes around $300 \mu$, tend to produce hatching juveniles rather than swim. ming larvae.

It seems probable that the amount of intracapsular nurse yolk available to each developing embryo is more important in dictating mode of development than is egg size. The importance of nurse yolk to developmental characteristics is reflected strongly in the variation seen within individual species, indeed within single broods. Thus, we note that the size of hatching young is variable in most of the species discussed here, and this variation undoubtedly arises from the ingestion of different quantities of available nurse yolk by different embryos. Such a relationship was previously suggested by THorson $(1950,1952)$ and Schmid (1954). Even more interesting is the versatility of the larvae in their response to a varying prehatching food supply: large embryos which have had 
a greater share of available yolk hatch as nonswimming juveniles; smaller larvae which have ingested less nurse yolk may be released as swimming veligers. We conclude, then, that the development of larvae and of post-larval characteristics is closely related to size and that this, in turn, is a function of nutrition.

A study of earlier papers by LACAzE-DUTHIERS (1860), Morton (1951, 1965), Habe (1953), and HaDFIELD (1966), clearly demonstrates what we have shown with only the Hawaiian vermetid fauna: that one cannot predict that animals with small eggs will have an indirect planktonic development. The amount of nurse yolk available to each developing embryo is smallest, both show the characteristic of a slit mantle with the egg capsules attached to the shell. The size compensations seem to be made only in the number of capsules concurrently brooded, up to 50 in $V$. alii, at most 6 in $D$. meroclista.

One might suggest that the reproductive habit is a characteristic of habitat, that the courses of currents or prevalence of heavy wave action might dictate the production of planktonic or non-planktonic juveniles. This does not appear to be the case. Vermetus alii, which lives in quiet lagoon-like waters, and Serpulorbis variabilis of open wave-swept shores, are the only two Hawaiian vermetid species which invariably produce planktonic larvae.

Table 1. Hawaïan Vermetidae. Reproductive habits

\begin{tabular}{|c|c|c|c|c|c|c|c|c|c|}
\hline Species & $\begin{array}{l}\text { Brooding } \\
\text { habit }\end{array}$ & $\begin{array}{l}\text { No. of egg } \\
\text { capsules } \\
\text { brooded } \\
\text { per female }\end{array}$ & $\begin{array}{l}\text { Capsule size } \\
(\mathrm{mm})\end{array}$ & $\begin{array}{l}\text { Form of } \\
\text { nurse yolk }\end{array}$ & $\begin{array}{l}\text { Egg size } \\
(\mathrm{mm})\end{array}$ & $\begin{array}{l}\text { No. of eggs } \\
\text { per capsule }\end{array}$ & $\begin{array}{l}\text { Protoconch } \\
\text { no. of } \\
\text { whorls }\end{array}$ & $\begin{array}{l}\text { Protoconch } \\
\text { size } \\
(\mathrm{mm})\end{array}$ & $\begin{array}{l}\text { Larval } \\
\text { develop- } \\
\text { ment }\end{array}$ \\
\hline $\begin{array}{l}\text { Dendropoma } \\
\text { meroclista }\end{array}$ & Shell & $3-6$ & $1.05 \times 0.79$ & None (?) & 0.270 & $3-16$ & $11 / 2$ & $0.45 \times 0.35$ & Mixed \\
\hline D. rhyssoconcha & Mantle & 6 & 2.00 & Vesicular & 0.315 & $6-25+$ & $11 / 2$ & $\mathrm{a} 0.58 \times 0.44$ & Direct \\
\hline D. gregaria & Mantle & $3-4$ & $1.00+$ & Vesicular & 0.310 & $6-21$ & $1 / / 2-2$ & $0.47 \times 0.41$ & Direct \\
\hline D. psarocephala & Mantle & 5 & 0.83 & Vesicular & 0.300 & $9-23+$ & $11 / 4+$ & $\mathrm{a} 0.50 \times 0.33$ & Direct \\
\hline D. platypus & Mantle & 5 & 3.00 & Vesicular & 0.350 & $24-70+$ & $1^{1 / 2}+$ & $0.60 \times 0.48$ & Mixed \\
\hline $\begin{array}{l}\text { Petaloconchus } \\
\text { keenae }\end{array}$ & Shell & $5+$ & $2.0-3.0$ & Nurse eggs & 0.217 & $\begin{array}{l}130-184 \\
(17-30 \\
\text { larvae) }\end{array}$ & $2^{1 / 2}-3$ & $90.66 \times 0.45$ & Mixed \\
\hline $\begin{array}{l}\text { Serpulorbis } \\
\text { variabilis }\end{array}$ & Shell & 48 & $4.0-5.0$ & Nurse eggs & 0.190 & 240 & $11 / 2$ & $0.29 \times 0.39$ & Indirect \\
\hline Vermetus alii & Mantle & 50 & 2.30 & - & 0.225 & 220 & 2 & $0.43 \times 0.34$ & Indireet \\
\hline
\end{tabular}

- Variable due to nurse yolk.

critical. On the other hand, species with especially large eggs, $250 \mu$ or more in diameter, would appear to consistently develop directly.

A brooding habit in the vermetids is constant, although two possible methods exist. The egg capsules may be brooded freely in the mantle cavity, in which case the mantle roof of the female is complete as in most prosobranchs, or capsules may be stalked and cemented to the dorsal shell of the female. In the latter instance, the pallial roof of the reproductive female is deeply incised in the dorsal mid-line and the egg capsules hang down through this cleft into the mantle chamber. The alternatives do not correlate with any other single factor such as generic distinetions, egg size, larval characteristics or size of the adult animals. Vermetus alii, the largest of the Hawaiian vermetids, and Dendropoma meroclista, the
Table 1 summarizes the information currently available on the reproductive and developmental characteristics of the Hawaiian Vermetidae.

Nurse yolk, consumed in different quantities by different embryos, leads not only to variation in tho larval mode of life but also to variation in size of the larva or juvenile and particularly in its shell. Thus, the protoconchs of directly developing individuals may be quite variable within species. For this reason, great caution must be used in ascribing taxonomic importance to protoconch size. However, within a given directlydeveloping species, the basic shape and number of whorls in the protoconch is relatively constant. This is not true in those species with indirect, planktotrophic larval phases. In Serpulorbis variabilis, for instance, the hatching protoconch (Fig. $19 \mathrm{~B}$ ) is small and highly conical. Late veligers of this species found 
in the plankton have much larger shells, of $2 \frac{1}{2}$ to 3 whorls which are smoothly barrel-shaped, not unlike the protoconch of Petaloconchus keenae.

\section{Summary}

1. Eight species of the gastropod family Vermetidae are presently recognized in the Hawaiian Islands. Seven are here described as new: Dendropoma meroclista, D. gregaria, D. psarocephala, D. rhyssoconcha, Petaloconchus keenae, Serpulorbis variabilis, and Vermetus alii. Dendropoma platypus was described by MöвсH in 1861. The descriptions include detailed information on shells, opercula, protoconchs, animals, brooding habits, distribution and habitats.

2. It is shown that the Hawaiian vermetid species fall well within the generic frameworks previously proposed by KEEN (1961) and MoRTon (1965).

3. All of the Hawaiian vermetids, except for Vermetus alii, feed predominantly by the mucous net method. $V$. alii feeds mainly by means of cilia on the ctenidial filaments, an ability shared to a lesser degree by the other local species. The two modes of feeding do not appear to be associated with any particular habitat.

4. Five vermetids are characteristic of the intertidal zone, with only one, Dendropoma gregaria, a gregarious-zone former. Serpulorbis variabilis and Dendropoma platypus occur where there is heavy-tomoderate wave action, Vermetus alii in quiet waters, and Petaloconchus keenae under all wave conditions.

5. Four vermetids are associated with subtidal reefs, with Petaloconchus keenae the most generally distributed with respect to substrate. Three small species of Dendropoma appear to be almost exclusively associated with coralline algal-covered substrates.

6. The Hawaiian vermetids all reproduce continuously. The eggs are brooded in capsules either freely in the mantle cavity or attached to the shell and hanging suspended in the mantle cavity through a deep cleft in the dorsal pallial wall of females.

7. Intracapsular nurse-yolk is ingested by the developing embryos of all species. Developmental pattern, direct versus indirect, seems more to be correlated with the amount of nurse yolk available to each embryo than to absolute egg size. Only Serpulorbis variabilis and Vermetus alii have obligatory planktonic phases. Some Dendropoma species and Petaloconchus keenae may produce a mixture of short-term planktonic and non-planktonic juveniles.

8. Variations in the amount of nurse yolk available to each embryo affect the size of the hatching protoconchs in the Dendropoma species and in Petaloconchus keenae. The protoconchs of Serpulorbis variabilis and Vermetus alïi may grow considerably during the planktonic phase, adding extra whorls to the shell.
Acknowledgements. We gratefully acknowledge the help of Dr.J.ARNOLD in preparing the photographs for this paper, and that of Mr. S. MichaEL in preparing the drawings of the opercula. We are also very appreciative of Mrs. J. B. TAYLOR's comments on planktonic stages among the Vermetidae. Parts of this research were supported by National Science Foundation grant GB-6134, to the 1968 Summer Training Program at the Hawaii Institute of Marine Biology, and by a grant to the senior author from the University of Hawaii Research Council.

\section{Literature cited}

Cranwhit, L. M. and L. B. Moorm: Intertidal communities of the Poor Knights Islands, New Zealand. Trans. Proc. N. Z. Inst. 67, 375-403 (1938).

Crossuand, C.: The oecology and deposits of the Cape Verde marine fauna. Proc. zool. Soc. Lond. 170-186 (1905).

HaBre, T.: Studies on the eggs and larvae of Japanese gastropods. Publs Seto mar. biol. Lab. 3, 161-167 (1953).

HADFIELD, M. G.: The reproductive biology of the California vermetid gastropods Serpulorbis squamigerus (CARPENTER, 1957) and Petaloconchus montereyensis. Doctoral dissertation, Stanford University. 174 pp. (1966).

- Observations on the anatomy and biology of two California Vermetid gastropods. Veliger 12 (3), 301-309 (1970).

KEEN, A. M.: Vermetid gastropods and marine intertidal zonation. Veliger 3 (1), 1-2 (1960).

- A proposed reclassification of the gastropod family Vermetidae. Bull. Br. Mus. nat. Hist. (Zool.) 7, 183-213 (1961).

- and J. E. Montox: Some new African species of Dendropoma (Vermetidae: Gastropoda). Proc. malac. Soc. Lond. 34 (1), 36-51 (1960).

KEMPF, M. and J. LABOREL: Formations de vermets et d'algues calcaires sur les côtes du Brasil. Recl Trav. Stn mar. Endoume 43 (59), 9—23 (1968).

LaOAZE-DUTHERR, M.: Mémoire sur l'anatomie et l'embryogénie des vermets. Annls Soi. nat. (Zool.) 13, 209-296 (1860).

Monton, J. E.: The structure and adaptations of the New Zealand Vermetidae. Parts I-III. Trans. Proc. R. Soc. N. Z. 79, 1-51 (1951).

- Form and function in the evolution of the Vermetidae. Bull. Br. Mus. nat. Hist. (Zool.) 11, 585-630 (1965).

SAFrim, U.: Recent vermetid formation on the Mediterranean shore of Israel. Proc. malac. Soc. Lond. 37, 27-34 (1966).

Scmmot, W. J.: Nahreier bei miozanen Vermetidae. Paläont. Z. 28, 167-171 (1954).

Stephanson, T. and A. Stephinson: The Bermuda Islands. Endeavour $13(50), 72-80$ (1954).

Thonson, G.: Reproductive and larval ecology of marine bottom invertebrates. Biol. Rev. 25, $1-45$ (1950).

- Zur jetzigen Lage der marinen Bodentier-Okologie. Verh. dt. zool. Ges. Wilhelmshaven 1951, 276-327 (1952).

YoNgE, C. M. : Notes on feeding and digestion in Pterocera and Vermetus, with a discussion on the occurrence of the crystalline style in the Gastropoda. Scient. Rep. Gt Barrier Reef Exped. 1, 259-281 (1932).

- and E. J. Ix.s: On the mantle cavity, pedal gland, and evolution of mucous feeding in the Vermetidae. Ann. Mag. nat. Hist. (Ser. 11) 3, 536-556 (1939).

First author's address: Dr. M. G. HADFIELD Pacific Biomedical Research Center

University of Hawaii

Honolulu, Hawaii

USA

Date of final manuscript acceptance: July 19, 1971. Communicated by J. BunT, Miami 